\title{
The Implementation of Hybrid Learning Strategies to Improve Students Learning Outcomes of Introduction to Microeconomics Subject in Economic Education Department Universitas Negeri Medan
}

\author{
Thamrin $^{1}$, Abdul Hasan Saragih ${ }^{2}$, Reza Aditia ${ }^{3}$ \\ \{thamrinpjt@gmail.com $\left.{ }^{1}\right\}$ \\ Universitas Negeri Medan, Medan, Indonesia ${ }^{1,2,3}$
}

\begin{abstract}
One of the implementations of information and communication technology (ICT) in teaching \& learning is through hybrid learning which is a combination of faceto-face instructional methods and online learning to answer the challenges of the fourth industrial revolution. This study aims to know the differences in learning outcomes Introduction to microeconomics between groups of students who are taught with hybrid learning with groups of students who are taught by direct learning. This research uses a quasi-experimental method. Data collection is done by conducting tests after learning process. The results of this study with the t-test at $\alpha 0.05$ stated that the learning outcomes of introduction to microeconomics were taught by hybrid learning is higher than the group of students who were taught by direct learning.
\end{abstract}

Keywords: hybrid learning, learning outcomes, introduction to microeconomics.

\section{Introduction}

Every lecturer hopes that the learning activities they carried out can achieve goals that are set effectively, efficiently, attractively and fun, in order to realize an active learning process and obtain maximum learning outcomes. To make that expectation, the lecturer must develop a learning design in accordance with experience. knowledge, skills and all available resources to support optimal achievement of each learning activity.

Introduction to microeconomics courses is part of the curriculum which is a subject of compulsory study in the Unimed economic education department with 3 credits weight. This course is very important considering that this course is a basic economic course that competence must be mastered by students as professional candidates for SMA / MA / SMK (high school and vocational school) economic teachers.

In an effort to maximize the introduction to microeconomics learning, teaching materials are available in the form of textbooks compiled by the KDBK team, but these teaching materials have not been packaged in module form and have not gone through the research and development $(\mathrm{R} \& \mathrm{D})$ process, have been validated, analyzed and developed before. Besides that the introduction tomicroeconomics teaching materials have not been packaged in a hybrid 
learning network or so that students can learn anytime and anywhere using their computers and smart phones.

The consequences of this condition have an impact on student competence that is less satisfying. This condition can be seen from the data of student learning 2017/2018 odd semester which shows that class A with 44 students only 3 people $(0.06 \%)$ get the maximum grade A. For class B with the number of students 37 people only 2 people $(0.05 \%)$ who get the maximum value of $\mathrm{A}$. Other phenomena can be seen through discussions with lecturers of KDBK micro teaching, one of the weaknesses is the lack of students' ability to master the material to be taught. This condition is suspected that when students attend introduction to microeconomics courses, they do not have optimal competence.

Based on in-depth interviews with 10 students from different classes, information was obtained that one of the causes of this condition was the teaching materials used in lectures that had not been standardized and were not attractive because they were still conventional and had not utilized information technology. Students also said that they wanted the need for IT-based module teaching materials in the form of hybrid learning. The need for teaching materials with hybrid learning is because the competence in this course is in the formof skills in calculating, analyzing and describing curves. In order for students to master this competency to the fullest, students must learn independently about the procedures for calculating, analyzing and describing curves on microeconomic problems.

This phenomenon certainly cannot be left behind, because it is feared that as prospective teachers they do not have professional competence that is capable when becoming an economics teacher, so that the profile of economic education department alumni become professional economics teachers in SMA / MA / SMK cannot be realized.

The effort that can be done to overcome the above problem is by developing teaching materials for introduction to microeconomics learning on hybrid learning. Hybrid learning is a combination of face-to-face learning strategies and online learning strategies that students will use independently to repeat their learning whenever and wherever students are.

In the 21 st century, today's students represent the first generation who grew up with new technology and are regarded as Z-generation digital natives. They spend their entire lives surrounded by and using computers, videogames, digital music players, video cameras, cell phones, and all toys and other tools from the digital age. Today, college graduates spend an average of less than 5,000 hours reading in their lives, but more than 10,000 hours of playing video game (not to mention 20,000 hours of watching TV) (Ceylan and Elitok Kesici 2017).

It was further explained that computer games, e-mail, the Internet, cell phones, and instant messaging are integral parts of their lives. Under these circumstances, policy makers of the school system must carry out renovations to educate a new generation. In connection with this phenomenon, if it is associated with learning, the teaching materials used in learning should be in line with the development of the 21 st century. Teaching materials are a set of material that is systematically arranged that allows students to learn and adapt to the existing curriculum.

Teaching materials are devices that contain material or content of learning to achieve learning objectives. A teaching material contains material or content in the form of ideas, facts, concepts, principles, rules, or theories that cover the subjects according to their discipline and other information in learning.

One of the many type of teaching material is module. Module is all forms of independent learning units designed for use by participants without the need to be guided by instructors / lecturers. So, themodule is an independent learning material specifically designed so that it can be studied by itself anytime, anywhere, by participants without the presence of instructors / lecturers. (Dirjen Belmawa, 2018). Usually the module is packaged in print, 
otherwise known as a print module. But, in online learning, the module can be packaged in the form of an online or hybrid module. "Hybrid" or "mix" is a name commonly used to describe courses that combine face-to-face classroom instruction with online learning. Hybrid learning based modules are learning that combines strategies for delivering learning using face-to-face activities and online (discussion / chat forums). Through hybrid learning based learning students are expected to be able to learn independently, sustainably, and develop throughout life so that learning will be more effective, more efficient, and more interesting (Tuapattinaya, 2017). Furthermore, Shea, Joaquin and Gorzycki (2015) state that hybrid learning, which combines face-to-face and online activities, is the fastest growing course in higher education.

Learning through this hybrid module has the advantage for students: (1) having greater time flexibility, freedom, and comfort by working part-time online from home (2). tend to interact more with lecturers and fellow students because there are many opportunities to do it both in class and online. (3) has access to the latest unlimited resources available via the Web. (4). can participate more in class discussions because they can choose an online or face-to-face environment where they feel more comfortable. (5). usually receive more feedback, and more frequent feedback from lecturers. (6). can acquire useful skills from using the Internet and computer technology.

Furthermore, Shea and Bidjerano (2013) explained that by using hybrid learning students have the opportunity to interact with lecturers, students with students and this interaction significantly influences learning outcomes. Online learning through hybrid is a fast-growing component of education (Means et al. 2009). Today many experts agree that mixed or hybrid learning, namely learning that combines face-to-face and online learning, is the most promising approach to increasing access to higher education and student learning outcomes (Means et al, 2010). In fact, the number of universities that use mixed courses is growing rapidly. Some estimate that between 80 and 90 percent of college and university programs will someday become hybrids and show that the number of integrated learning classrooms has increased 30 percent each year (Horn \& Staker, 2011).

This hybrid module element is the same as the print module, but because it will be presented online, the elements of this module are presented in online media. These elements are: (1). Preliminary Section; contains a brief description, relevance, learning instructions and learning outcomes. All components are presented in the form of fragments of digital material such as descriptive text on the web, presentation slides (ppt), text (pdf), video, animation and others. (2) Core Section; contains a description or explanation of the material, examples, illustrations, exercises and others. The material is presented in the form of fragments of digital material such as descriptive text on the web, presentation slides (ppt), text (pdf), video, animation and others. (3) Closing Section; contains summaries / conclusions, tests, assignments, answer keys, reference lists and others. These components are presented in the form of fragments of digital material such as descriptive text on the web, presentation slides (ppt), text (pdf), video, animation and others. (Dirjen Belamawa, 2017). This hybrid module will be arranged in e-learning Moodle platform.

\section{Methodology}

The purpose of this study was to determine differences in introduction to microeconomics learning outcomes between groups of students taught with hybrid learning strategies and groups of students taught with direct learning strategies. This research was conducted in 
Unimed Economic Education department. The population in this study were all students of semester I economic education department 2016/2017 academic year. Samples were taken by random sampling of two classes. The experimental class consisted of 24 students of each class. The data that used in this study are learning outcomes from the introduction to microeconomics. The instrument used has been tested for validity and reliability.

Analysis used to process the data in this study is t test, using SPSS 17.0 for Windows program after an analysis prerequisite test conducted.

\section{Result And Discussion}

Table 1.Introduction To Microeconomics Students Learning Outcomes.

\begin{tabular}{lll}
\hline Statistic & $\begin{array}{l}\text { HYBRID LEARNING } \\
\text { (Experimental class) }\end{array}$ & $\begin{array}{l}\text { Direct Learning } \\
\text { (Control Class) }\end{array}$ \\
\hline Mean & 76,37 & 71,80 \\
Minimum & 55,86 & 55,86 \\
Maximum & 94,08 & 85,26 \\
Std.Deviation & 10,89 & 7,612 \\
\hline
\end{tabular}

Table 1 shows that the average introduction to microeconomics learning outcomes of experimental class students by applying HYBRID LEARNING strategies have an average score of 76.37, higher than the average control class with an average score of 71.80 . The highest score in the experimental class is 94.08 and the control class is 85.26.

Hypothesis test results of the implementation of the HYBRID LEARNING on introduction to microeconomic student learning outcomes are presented in Table 2.

Table 2.Analysis Results Summary Of Hybrid Learning Strategy On The Results Of Introduction To Microeconomics Students.

\begin{tabular}{|c|c|c|c|c|c|c|}
\hline & \multicolumn{6}{|c|}{ T-test for Equality of Means } \\
\hline & $\mathrm{t}$ & Df & Sig & Mean & $95 \% \mathrm{C}$ & fidence Interval \\
\hline & & & & $\begin{array}{l}\text { Differre } \\
\text { nce }\end{array}$ & Lower & Upper \\
\hline $\begin{array}{l}\text { Learning } \\
\text { outcomes }\end{array}$ & 2,31 & 78,9 & 0,023 & 4,57 & .645 & 8.50 \\
\hline
\end{tabular}

From Table 2 can be seen the results of the calculation of the analysis of differences in the results of introduction to microeconomics learning groups of students taught with hybrid learning and direct learning strategies at the value of $\mathrm{Sig}=0.023$ with a significance level of $5 \%$. This means that if the probability significance (p-value) is $<0.05$, the null hypothesis (Ho) is in the rejection area because of the probability significance (p-value) $<\alpha(0.05)$. Calculations on student economic learning outcomes, Ho was rejected so that Ha was accepted on economic introductory learning outcomes between the control group with direct learning and the experimental group with hybrid learning was significantly different so that the application of hybrid learning had an effect on student economic learning outcomes. 
This finding is in line with research result of Olapiriyakul \& Scher (2006) that demonstrated the majority of students who participated in the hybrid learning course are active/ sensing/sequential/visual learners. Most of them preferred visual presentations to verbal explanations.

Similar with it, the study of Hall \& Davison (2007) also states blogs (online teaching) offer comparable and additional benefits to other projects designed to encourage reflective engagement with teaching material.

\section{Conclusions}

Based on the results of the study and discussion can be summarized as follows:

1. There are significant differences in introduction to microeconomic learning outcomes between groups of students taught with hybrid learning with groups of students taught with direct learning strategies.

2. The application of hybrid learning strategies has a significant effect on improving the learning outcomes of introduction to microeconomicss students.

\section{Suggestions}

1. Based on the average score of introduction to microeconomic learning outcomes of groups of students taught with hybrid learning strategies higher than the student groups taught with direct learning strategies, it is suggested that inroduction to economic lecturers can be advised to apply this hybrid learning strategy in this subject..

2. Lecturer could be more familiar with technology so they could use this hybrid learning effectively.

\section{References}

[1]Ceylan, VeyselKarani and Ayşe ElitokKesici. 2017. "Effect of Blended Learning to Academic Achievement. "Journal of Human Sciences 14(1):308.

[2]DirjenBelmawa 2018. PetunjukTeknisPengembanganModul Hybrid Learning PPG dalamJabatan, Jakarta, DirektoratPembelajaranDirektoratJenderalPembelajarandanKemahasiswaanKemristekDikti

[3]Hall, Hazel and Brian Davison. 2007. "Social Software as Support in Hybrid Learning Environments: The Value of the Blog as a Tool for Reflective Learning and Peer Support." Library and Information Science Research 29(2):163-87.

[4]Horn, M. B., \&Staker, H. (2011). The rise of K-12 blended learning. Innosight institute, 5.

Means, B. (2010). Technology and education change: Focus on student learning. Journal of research on technology in education, 42(3), 285-307.

[5]Means, Barbara, Yukie Toyama, Robert Murphy, Marianne Bakia, and Karla Jones. 2009. "Evaluation of Evidence-Based Practices in Online Learning." Structure 66.

[6]Olapiriyakul, Kamolbhan and Julian M. Scher. 2006. "A Guide to Establishing Hybrid Learning Courses: Employing Information Technology to Create a New Learning Experience, and a Case Study." Internet and Higher Education 9(4):287-301.

[7]Prelly M. J. Tuapattinaya. 2017. "Jurnal Biology Science \& Education 2017 Prelly m. j. T." 1(1):186-92. 
[8]Shea J. Joaquin M. E. Gorzycki M. (2015). Hybrid course design: Promoting student engagement and success. Journal of Public Affairs Education, 21, 539-556

[9]Shea, P., \&Bidjerano, T. (2010). Learning presence: Towards a theory of self-efficacy, selfregulation, and the development of a communities of inquiry in online and blended learning environments. Computers \& Education, 55 